\title{
THE ANTHOCYANIN CONTENT AND BIOACTIVITY OF CORNELIAN CHERRY (Cornus mas) AND WILD BLACKBERRY (Rubus fruticosus) FRUIT EXTRACTS FROM THE VLASINA REGION
}

Ana Milenković Anđelković1*, Blaga Radovanović1, Marko Anđelković1, Aleksandra Radovanović ${ }^{1}$, Vesna Nikolić ${ }^{2}$, Vladimir Ranđelović ${ }^{3}$

${ }^{1}$ Faculty of Science and Mathematics, Department of Chemistry, University of Nišs, Niš, Serbia
2Faculty of Technology, University of Niš, Leskovac, Serbia

${ }^{3}$ Faculty of Science and Mathematics, Department of Biology, University of Niš, Niš, Serbia

The aim of this study was to assess antioxidant and antimicrobial activities of anthocyanin rich extracts of two wild berry fruit species from the Vlasina region, namely, cornelian cherry (Cornus mas) and wild blackberry (Rubus fruticosus). The phenol and anthocyanin content was determined using spectrophotometric and high performance liquid chromatography (HPLC) assays. The antioxidant activity was estimated by $2,2^{\circ}$ - diphenyl-1-picrylhydrazyl (DPPH) assay, while disc diffusion and broth microdilution tests were carried out to determine the antimicrobial activity. All extracts showed high radical scavenging activity and antimicrobial activity on all tested bacterial strains. The extracts of wild berry fruits can be suitable for the preparation of different nutritional and pharmaceutical ingredients.
(ORIGINAL SCIENTIFIC PAPER) UDC 547.973:582.788.1+582.712

Keywords: Cornelian cherry, wild blackberry, anthocyanin, antioxidant, antimicrobial activity

\section{Introduction}

Blackberry (Rubus fruticosus) is a perennial shrub, native to Europe. It prefers well-drained, loamy and moist soils. Blackberry is very tolerant of poor soils and in folk medicine was usually used to treat dysentery, diarrhea, hemorrhoids and cystitis [1-5]. It can be used as prevention against heart disease, cancer and eye degenerations. The leaves are useful in traditional phytotherapy treatments of wounds, sores, scratches, gum inflammations, ulcers and sore throat in Mediterranean countries [1-5]. Blackthorn (Prunus spinosa L.) is native to Europe, western Asia and Northwest Africa.

Cornelian cherry (Cornus mas) is a deciduous shrub, growing 5 to 12 meters tall. The plant is native to south Europe and southwest Asia. Traditionally, cornelian cherry was applied in cases of fevers (bark, shoots and root) and diarrhea (fruit). Today, it is used for various ailments: stomach ache and cramps, diarrhea, different skin infections, intestinal parasites and hemorrhoids.

There are a number of studies on different berry fruit phenols and their antioxidant and antimicrobial activities [5-10] but rare for wild species. Our aim was to determine and compare the anthocyanin composition in the extracts of wild berry fruits from southeast Serbia, namely cornelian cherry (Cornus mas), and wild blackberry (Rubus fruticosus), as well as their antioxidant and antimicrobial activities.

\section{Experimental}

\section{Chemicals}

Acetonitrile, methanol and acetic acid of HPLC-grade were obtained from Merck (Darmstadt, Germany); 2,2`- diphenyl-1-picrylhydrazyl (DPPH) free radical and pure anthocyanin standards were supplied from Sigma Chemical Co. (St. Louis, MO, USA). The reagents were of analytical quality.

\section{Samples}

The samples of wild fruits were collected in the Vlasina region (Natural Park) which is located in Southeast Serbia. The climate of this region is typical of mountains with the absolute maximum air temperature of $31.6^{\circ} \mathrm{C}$, and minimum of $-31.5^{\circ} \mathrm{C}$. Wild blackberry (Rubus fruticosus) and cornelian cherry (Cornus mas) were harvested at the commercial maturity stage in July - August 2012. Immediately after harvesting, the fruits were frozen and stored at $-20^{\circ} \mathrm{C}$ until analysis.

Voucher specimens were deposited in the Herbarium of the Institute of Botany and Botanical Garden "Jevremovac", Faculty of Biology, University of Belgrade, under accession number 16634 (Cornus mas) and 16636 (Rubus fruticosus), BEOU [11]. The plant species were identified by Prof. Dr Vladimir Ranđelović, Faculty of for Mathematics and Science, Department of Biology, University of Niš.

\footnotetext{
* Author address: Ana Milenković Anđelković, Faculty of Science and Mathematics, Department of Chemistry, University of Niš, Višegradska 33, 18000 Niš, Serbia

E-mail: ana.andjelk@gmail.com

The manuscript received: June, 16, 2015

Paper accepted: July, 22, 2015
} 
Preparation of extracts

The fresh fruits $(10 \mathrm{~g})$ were crushed in a grinder for $2 \mathrm{~min}$, extracted three times with $35 \mathrm{ml}$ acidified methanol solution (formic acid/methanol/water, 0.1/70/29.9, v/v/v\%) in a magnetic stirrer for $24 \mathrm{~h}$ in the dark and then centrifuged for $10 \mathrm{~min}$ at $4000 \mathrm{rpm}$. The extracts were combined and purified through a $0.45 \mu \mathrm{m}$ syringe filter (Millipore) before analyses.

\section{Determination of antioxidant activity}

Total phenol content was determined spectrophotometrically $[12,13]$. The dilute extract was mixed with $2 \% \mathrm{HCl}$ in $95 \%$ ethanol approximately $15 \mathrm{~min}$ before reading the absorbance at $280 \mathrm{~nm}$ with a UV/Vis Agilent 8453 spectrophotometer. The absorbance A280 nm was used to estimate phenolics (gallic acid was used as a standard).

The radical scavenging activity (RSA, \%) of the wild fruit extracts was analyzed by using DPPH assay [14,15]. The antioxidant assay is based on the measurement of the loss of DPPH color by change of absorbance at $515 \mathrm{~nm}$ caused by the reaction of DPPH with the tested sample. The reaction was monitored by a UV/Vis spectrophotometer. The diluted extract and fresh $1 \times 10^{-4} \mathrm{M}$ DPPH methanolic solution were put into a cuvette at the room temperature. After the 20 min incubation period at room temperature, the absorbance was read against a blank (the absorbance of the diluted sample extract) at $515 \mathrm{~nm}$.

Radical scavenging activity (RSA, \%) of each extract was calculated from the decrease of absorbance according to Eq 1.

$\operatorname{RSA}(\%)=[(1-$ Asample - Ablank $) /($ Acontrol $)] 100$

where Acontrol is the absorbance of the control reaction, Ablank is the absorbance of the dilute extract and Asample is the absorbance of the extract with DPPH radical.

RSA was plotted against the extract concentration $(\mathrm{ml} / \mathrm{g})$ to determine the concentration of the extract that reduces the activity by $50 \%\left(\mathrm{EC}_{50}\right)$.

High performance liquid chromatography (HPLC) analysis

Anthocyanins were analyzed by direct injection of the extracts, previously filtered through a $0.45 \mu \mathrm{m}$ pore size membrane filter, in an Agilent Technologies 1200 chromatographic system equipped with a quaternary pump, an Agilent diode array detector 1200 with RFID tracking technology for flow cells and UV lamp and 1200 Fluorescence Detector for multi wavelength detection, on-line acquisition of Ex and Em spectra, 8ul flow cell, an automatic injector, and a ChemStation software. The column was thermostated at $30{ }^{\circ} \mathrm{C}$. After injecting $5 \mu$ of the extract, the separation was performed in an Agilent-Eclipse XDB C-18 4.6 $\times 150 \mathrm{~mm}$ column. The HPLC grade solvents used were formic acid/water as solvent $A$ and acetonitrile/formic acid/ water as solvent $B$. The elution profile was as follows: 0 $\min , 100 \%$ A, 0\% B; $10 \mathrm{~min}, 90 \% \mathrm{~A}, 10 \% \mathrm{~B} ; 20 \mathrm{~min}, 80 \%$ A, 20\% B; 30 min, $70 \%$ A, 30\% B: 35 min, 50\% A, 50\% B; $40 \mathrm{~min}, 20 \% \mathrm{~A}, 80 \% \mathrm{~B}$. The system was equilibrated using starting conditions for 10 min prior to injection of the next sample. The flow-rate was at $0.8 \mathrm{ml} / \mathrm{min}$ [13]. The detection wavelength was $520 \mathrm{~nm}$. The identification and quantitation of anthocyanin compounds were made by means of a calibration curve obtained with standard solutions of pure anthocyanin standards and with the data given in the literature [6]. The results were expressed as $\mathrm{mg} / \mathrm{kg}$ fruit.

Antimicrobial activity

The antimicrobial activity of the test samples was evaluated using the following laboratory control strains: Clostridium perfringens ATCC 19404, Bacillus subtilis ATCC 6633, Listeria innocua ATCC 33090, Staphylococcus aureus ATCC 6538, Sarcina lutea ATCC 9341 and Micrococcus flavus ATCC 40240 (Gram (+) bacteria), Escherichia coli ATCC 25922, Pseudomonas aeruginosa ATCC 9027, Salmonella enteritidis ATCC 13076, Shigella sonnei ATCC 25931, Klebsiella pneumoniae ATCC 10031 and Proteus vulgaris ATCC 8427 (Gram (-) bacteria) obtained from the American Type Culture Collection. The inocula of the bacterial strains were prepared from overnight broth cultures and suspensions were adjusted to $0.5 \mathrm{McF}$ arland standard turbidity (corresponding to $10^{7}-10^{8} \mathrm{CFU} / \mathrm{ml}$, depending on genera - consensus standard by National Committee for Clinical Laboratory Standards (NCCLS). Preliminary antimicrobial tests were carried out by a disc diffusion method using $100 \mu \mathrm{l}$ of bacterial suspension spread on MuellerHinton agar

(MHA, Torlak) in sterilized Petri dishes (90 mm in diameter). The discs (9 $\mathrm{mm}$ in diameter, HiMedia Laboratories Pvt. Limited) were impregnated with $50 \mu \mathrm{l}$ of the testing samples and placed on the inoculated agar $(20 \mathrm{ml})$. The inoculated plates were incubated for $24 \mathrm{~h}$ at $37^{\circ} \mathrm{C}$. Reference

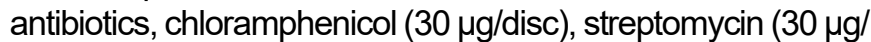
disc) and tetracycline (30 $\mu \mathrm{g} /$ disc) served as a positive control, while the solvent (water - $50 \mu \mathrm{l} / \mathrm{disc}$ ) was used as a negative control. The solvent (water) showed no inhibitory activity. All the tests were performed in triplicate. The antibacterial activity was evaluated by measuring the zone of inhibition (in $\mathrm{mm}$ ) against the test bacterial strains. A broth microdilution method was used to determine the minimum inhibitory concentration (MIC) and minimum bactericidal concentration (MBC) according to the National Committee for Clinical Laboratory Standards. The inocula of the bacterial strains were prepared from overnight broth cultures and suspensions were adjusted to $0.5 \mathrm{McF}$ arland standard turbidity. A serial doubling dilutions of the testing samples were prepared in a 96/well microtiter plate over the range of $500-0.25 \mu \mathrm{l} / \mathrm{ml}$ in inoculated nutrient broth (the final volume - $100 \mu \mathrm{l}$ and the final bacterial concentration was $10^{6}$ $\mathrm{CFU} / \mathrm{ml}$ in each well). The plate was incubated for $24 \mathrm{~h}$ at $37{ }^{\circ} \mathrm{C}$. All experiments were performed in triplicate. Two growth controls consisting of medium with water (negative control) and medium with chloramphenicol, streptomycin and tetracycline (positive control) were also included. The microbial growth was determined by absorbance at $620 \mathrm{~nm}$ using the universal microplate reader (ThermoLab systems, Multiskan EX, Software for Multiscan ver.2.6.). MIC was defined as the lowest concentration of the test samples at 
which microorganisms showed no visible growth. In order to determine MBC, broth was taken from each well without the visible growth and inoculated on Mueller Hinton agar $(\mathrm{MHA})$ for $24 \mathrm{~h}$ at $37^{\circ} \mathrm{C}$. The MBC is defined as the lowest concentration of the test samples at which $99.9 \%$ of inoculated microorganisms were killed.

\section{Data analysis}

Three analytical replicates were carried out on each sample. The concentration of phenolic compounds was measured and analyzed using one-way ANOVA. The measurements were averaged and the results are given as mean \pm standard deviation (SD), calculated by the analysis of variance using the Minitab statistical package, version 15 (Minitab Inc, State College, Pennsylvania, USA).

\section{Results and discussion}

The total phenol content and radical scavenging activity in blackberry and cornelian cherry extracts are presented in Table 1.

Table 1. The total phenol content and radical scavenging activity of the wild fruit extracts as EC50 values

\begin{tabular}{lcc}
\hline & Cornelian cherry & Wild blackberry \\
\hline Total phenols $\left(\mathrm{mg} \mathrm{GAE}^{\mathrm{a}} / \mathrm{kg}\right)$ & $8625.89 \pm 20.17$ & $7838.26 \pm 21.43$ \\
$\mathrm{EC}_{50}(\mathrm{ml} / \mathrm{g})$ & $22.19 \pm 0.98$ & $31.18 \pm 1.13$
\end{tabular}

Values are the mean \pm standard deviation $(n=3)$; ${ }^{\text {a }}$ Gallic acid equivalent

The results show high concentrations of total phenols in all fruit extracts which is in agreement with literature data $[6,7,16]$.

In order to determine the anthocyanin profile of the investigated fruit extracts, the HPLC method was applied. The HPLC chromatograms of the investigated fruit extracts showed quite different anthocyanin composition (Figures 1 and 2).

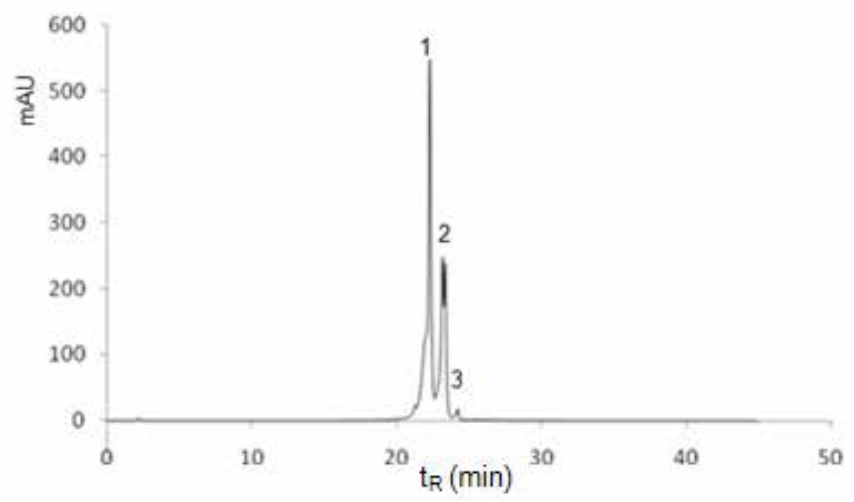

Figure 1. The HPLC chromatogram of the anthocyanin composition of the cornelian cherry (Cornus mas) fruit extract: 1 cyanidin-3-galactoside, 2 pelargonidin-3-glucoside, 3 delphinidin-3-galactoside

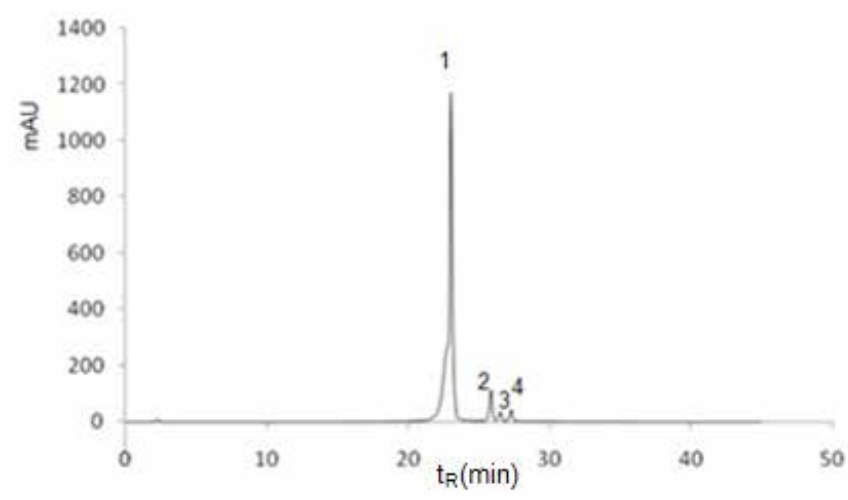

Figure 2. The HPLC chromatogram of the anthocyanin composition of the wild blackberry (Rubus fruticosus) extract: 1 cyanidin-3-glucoside, 2 cyanidin-3-rutinoside, 3 cyanidin-3-arabinoside, 4 cyanidin-3-(6-o-malonyl) glucoside

The concentrations of these anthocyanins found in fruit extracts are shown in Table 2.

Table 2. The content of anthocyanins of wild fruit extracts (mg/ $\mathrm{kg}$ fresh weight)

\begin{tabular}{lcc}
\hline Compound & Cornelian cherry & Wild blackberry \\
\hline cyanidin-3-galactoside & $1006.78 \pm 11.72$ & nd \\
cyanidin-3-glucoside & nd & $2054.11 \pm 15.98$ \\
cyanidin-3-rutinoside & nd & $147.26 \pm 2.74$ \\
cyanidin-3-arabinoside & nd & $49.78 \pm 1.92$ \\
cyanidin-3-malonyl glucoside & nd & $157.04 \pm 3.11$ \\
pelargonidin-3-glucoside & $327.29 \pm 4.13$ & $\mathrm{nd}$ \\
delphinidin-3-galactoside & $49.13 \pm 2.16$ & $\mathrm{nd}$ \\
peonidin-3-glucoside & $\mathrm{nd}$ & $\mathrm{nd}$ \\
peonidin-3-rutinoside & $\mathrm{nd}$ & $\mathrm{nd}$ \\
$\sum$ Anthocyanins & $1383.20 \pm 7.81$ & $2408.19 \pm 14.27$
\end{tabular}

Values are the mean \pm standard deviation $(n=3)$

These results showed that wild blackberry fruit extract had a significantly higher total anthocyanin content comparing to the cornelian cherry fruit extract.

Cyanidin-3-galactoside, pelargonidin-3-glucoside and delphinidin-3-galactoside were anthocyanins which were only found in cornelian cherry fruit extracts (Figure 1). Our results of the anthocyanin qualitative composition was similar with those previously described [8]. Pelargonidin-3-glucoside was the predominant anthocyanin, followed by cyanidin-3-galactoside. Delphinidin-3-galactoside was the least abundant one and present only in $3 \%$ (Table 2).

Blackberry extract showed the presence of only cyanidin-based compounds (Figure 2) which is also reported by others $[9,10]$. The most abundant anthocyanin compound was cyanidin-3-glucoside which represents $85.29 \%$ of the total anthocyanin content found in blackberry extract (Table 2). Other detected compounds were cyanidin-3-malonyl glucoside $(6.52 \%)$, cyanidin-3-rutinoside $(6.11 \%)$, and cyanidin-3-arabinoside $(2.07 \%)$.

There are a number of reports on the antioxidant activities of fruit extracts determined by several methods 
$[9,10,17]$. In order to evaluate the antioxidant activity of wild red fruits, DPPH assay was applied. The European cornel fruit extract showed lower $E_{50}$ value and indicted a higher DPPH scavenging activity than the wild blackberry fruit extract. A correlation of antioxidant activities of these extracts with their total phenolic content and anthocyanins was investigated. A significant value for the determination coefficient $(R 2=0.9455, p<0.001)$ was obtained for the correlation between the antioxidant activity and the total phenolics content and no correlation was found in the case of the antioxidant activity vs. the anthocyanin content.

The antimicrobial activity data for all investigated extracts of wild berry fruits are given in Tables 3 and 4 .

Table 3. Diameters of the inhibition zone (in $\mathrm{mm}$ ) for the extracts $(50 \mu \mathrm{l} / \mathrm{disc})$

\begin{tabular}{lccccc}
\hline Bacterial strains & $\begin{array}{c}\text { Cornelian } \\
\text { cherry }\end{array}$ & $\begin{array}{c}\text { Wild } \\
\text { blackberry }\end{array}$ & St. & Ch. & Tet. \\
\hline Gram negative strains & & & & & \\
Escherichia coli & $12.2 \pm 2.0$ & $12.1 \pm 1.0$ & $16.0 \pm 1.2$ & $\mathrm{nt}$ & $23.2 \pm 1.2$ \\
Pseudomonas aeruginosa & $13.7 \pm 1.2$ & $14.2 \pm 1.3$ & $23.0 \pm 1.0$ & $\mathrm{nt}$ & $20.8 \pm 1.5$ \\
Salmonella enteritidis & $12.8 \pm 2.0$ & $13.7 \pm 1.3$ & $18.0 \pm 1.0$ & $\mathrm{nt}$ & $23.3 \pm 1.3$ \\
Shigella sonnei & $11.1 \pm 1.8$ & $12.0 \pm 1.0$ & $19.0 \pm 2.0$ & $\mathrm{nt}$ & $31.1 \pm 0.8$ \\
Klebsiella pneumoniae & $13.7 \pm 1.8$ & $13.8 \pm 1.6$ & $\mathrm{nt}$ & $\mathrm{nt}$ & $23.6 \pm 0.6$ \\
Proteus vulgaris & $12.9 \pm 1.8$ & $13.2 \pm 1.4$ & $\mathrm{nt}$ & $\mathrm{nt}$ & $19.2 \pm 0.5$ \\
Gram-positive strains & & & & & \\
Clostridium perfringens & $13.8 \pm 0.9$ & $14.2 \pm 3.1$ & $\mathrm{nt}$ & $\mathrm{nt}$ & $29.0 \pm 2.0$ \\
Bacillus subtillis & $13.6 \pm 2.4$ & $13.4 \pm 2.3$ & $\mathrm{nt}$ & $26.0 \pm 1.1$ & $23.9 \pm 1.0$ \\
Staphylococcus aureus & $13.3 \pm 3.1$ & $14.0 \pm 0.9$ & $\mathrm{nt}$ & $25.0 \pm 1.2$ & $18.5 \pm 1.3$ \\
Listeria inocua & $15.4 \pm 2.5$ & $15.9 \pm 1.6$ & $\mathrm{nt}$ & $18.0 \pm 2.0$ & $18.7 \pm 1.2$ \\
Sarcina lutea & $13.7 \pm 1.2$ & $14.1 \pm 1.4$ & $\mathrm{nt}$ & $38.0 \pm 2.0$ & $20.0 \pm 1.2$ \\
Micrococcus flavus & $13.4 \pm 1.9$ & $13.7 \pm 0.9$ & $\mathrm{nt}$ & $35.0 \pm 2.1$ & $23.6 \pm 0.7$ \\
\hline
\end{tabular}

The values are the means \pm standard deviation values $(n=3)$; St. - Streptomycin; Ch. - Chloramphenicol; Tet. - Tetracyclin; nt - not tested

Table 4. Antibacterial (MIC) and bactericidal (MBC) activities of the extracts and reference antibiotics MIC/MBC $(\mu \mathrm{g} / \mathrm{ml})$

\begin{tabular}{|c|c|c|c|c|c|}
\hline \multirow[b]{2}{*}{ Bacterial strains } & \multirow{2}{*}{$\begin{array}{c}\text { Cornelian } \\
\text { cherry }\end{array}$} & \multirow{2}{*}{$\begin{array}{c}\text { Wild } \\
\text { blackberry }\end{array}$} & \multicolumn{3}{|c|}{ Antibiotics } \\
\hline & & & St. & Ch. & Tet. \\
\hline \multicolumn{6}{|l|}{ Gram negative strains } \\
\hline Escherichia coli & $250 / 500$ & $500 / 500$ & $16 / 16$ & nt & $3.8 / 7.5$ \\
\hline Pseudomonas aeruginosa & $500 / 500$ & $250 / 250$ & $8 / 8$ & nt & $7.5 / 7.5$ \\
\hline Salmonella enteritidis & $62.5 / 125$ & $62.5 / 62.5$ & $4 / 4$ & nt & $0.9 / 1.9$ \\
\hline Shigella sonnei & $250 / 250$ & $125 / 125$ & $16 / 16$ & nt & $0.06 / 0.12$ \\
\hline Klebsiella pneumoniae & $500 / 500$ & $250 / 250$ & nt & nt & $0.9 / 1.9$ \\
\hline Proteus vulgaris & $500 / 500$ & $250 / 250$ & nt & nt & $1.9 / 1.9$ \\
\hline \multicolumn{6}{|l|}{ Gram-positive strains } \\
\hline Clostridium perfringens & $500 / 500$ & $250 / 250$ & nt & $1 / 8$ & $0.9 / 0.9$ \\
\hline Bacillus subtillis & $62.5 / 125$ & $125 / 125$ & nt & $8 / 8$ & $0.9 / 0.9$ \\
\hline Staphylococcus aureus & $125 / 125$ & $62.5 / 125$ & nt & $2 / 16$ & $0.12 / 0.9$ \\
\hline Listeria inocua & $125 / 125$ & $62.5 / 62.5$ & nt & $8 / 18$ & $0.46 / 0.9$ \\
\hline Sarcina lutea & $125 / 125$ & $62.5 / 62.5$ & nt & $0.5 / 2$ & $0.06 / 0.06$ \\
\hline Micrococcus flavus & $250 / 250$ & $125 / 125$ & nt & $1 / 1$ & $0.4 / 0.9$ \\
\hline
\end{tabular}

St. - Streptomycin; Ch. - Chloramphenicol; Tet. - Tetracyclin; nt - not tested

Inhibition zone diameters of the tested wild fruits ( $50 \mu \mathrm{l} / \mathrm{disc}$ ) were $11.1-15.9 \mathrm{~mm}$, which is quite significant in comparison to the reference antibiotics (from $16.0-38 \mathrm{~mm}$ ). The lowest activity was evaluated against the following strains: $S h$. sonnei and E. coli. Generally, gram (-) bacteria showed lower inhibition zone diameters than gram (+) bacteria. The wild blackberry fruit extract was slightly more effective than the cornelian cherry fruit extract (Table 3).

The results obtained by the microdilution method confirmed disc diffusion results in most cases. The tested fruit extracts showed the antimicrobial activity against all tested strains in the range from $62.5-500 \mu \mathrm{g} / \mathrm{ml}$ (Table 4). It can be noticed that the cornelian cherry fruit extract possesses a weaker activity, with the exception of $E$. coli and $B$. subtillis, against which it exhibited a higher activity than the wild blackberry extract. Among gram (-) bacteria, the most sensitive was $S$. enteritidis, while in the group of Gram (+) bacteria, they were $L$. inocua and $S$. aureus. Generally, the group of gram (-) bacteria were more resistant on the tested extracts compared to the 
investigated group of gram (+) bacteria. Also, it must be pointed out that in the cases of almost all tested samples, MIC was equal to MBC (Table 4), meaning that the determined critical concentration of antimicrobial compounds has mostly bactericidal activity.

Fruit extracts represent a complex system rich in phenolic compounds, among them anthocyanins in a significant quantity, but also the other compounds such as ascorbic acid. The fact that total phenolic contents of the investigated extracts did not correlate with the antimicrobial activity of the extracts and, on the other hand, the presence of the correlation between the total anthocyanin content and antimicrobial activity was obvious (extracts of blackberries were rich in anthocyanins and showed a stronger antimicrobial activity) favor the suggestion that anthocyanins possess certain antimicrobial properties. These properties can be consequences of both, significant amounts of anthocyanins present in the extracts and also their effects (additive, synergistic, etc.) on other components present in complex mixtures such as extracts of wild berry fruits.

\section{Conclusion}

All investigated extracts of wild berry fruits contain a high total phenolic content and show a high antioxidant activity. These extracts were rich in quite different anthocyanins, but a phenolic group was not directly connected with their strong antioxidant activity suggesting that other compounds (other phenolics, ascorbic acid, etc.) present in the extracts are also involved in the antioxidant action. On the other hand, the antimicrobial activity of the tested extracts, mainly antibacterial, against almost all the tested bacterial strains showed certain correlations with the total anthocyanin content. These bioactivities showed that wild berry fruits can be exploited for the preparation of different nutritional and pharmaceutical ingredients.

\section{Acknowledgments}

The present research was supported by the EU, FP7 Regpot - 2007- 3-01, the project «Chromlab-Antioxidant ", No. 204756 and by the Ministry of Education and Science of the Republic of Serbia, project No. 34012, 31020 and 176006.

\section{References}

[1] L. Panizzi, C. Caponi, S. Catalano, P. L. Cioni, I. Morelli, In vitro antimicrobial activity of extracts and of isolated constituents of Rubus ulmifolius, Journal Ethnopharmacology, 79 (2002) 165-168.

[2] S. Martini, C. D'Addario, A. Colacevich, S. Focardi, F. Borghini, A. Santucci, N. Figura, C. Rossi, Antimicrobial activity against Helicobacter pylori strains and antioxidant properties of blackberry leaves (Rubus ulmifolius) and isolated compounds, International Journal of Antimicrobial Agents, 34 (2009) 50-59.

[3] P. M. Guarrera, Traditional phytotherapy in central Italy
(Marche, Abruzzo, and Latium), Fitoterapia, 76 (2005) $1-25$.

[4] N. Erdemoglu, E. Kupeli, E. Yesilada, Anti-inflammatory and antinociceptive activity assessment of plants used as remedy in Turkish folk medicine, Journal of Ethnopharmacology, 89 (2003) 123-129.

[5] A. V. Patel, J. Rojas-Vera, C. G. Dacke, Therapeutic constituents and actions of Rubus species, Current Medicinal Chemistry, 11 (2004) 1501-1512.

[6] C. Mertz, V. Cheynier, Z. Günata, P. Brat, Analysis of Phenolic Compounds in Two Blackberry Species (Rubus glaucus and Rubus adenotrichus) by High-Performance Liquid Chromatography with Diode Array Detection and Electrospray Ion Trap Mass Spectrometry, Journal of Agricultural and Food Chemistry, 55 (2007) 8616-8624.

[7] M. N. Stefanut, A. Cata, R. Pop, C. Mosoarca, A. D. Zamfir, Anthocyanins HPLC-DAD and MS characterization, total phenolics, and antioxidant activity of some berries extracts, Analytical Letters, 44 (2011) 2843-2855.

[8] A.M. Pawlowska, F. Camangi, A. Braca, Quali-quantitative analysis of flavonoids of Cornus mas L. (Cornaceae) fruits, Food Chemistry, 119 (2010) 1257-1261.

[9] H. J. Fan-Chiang, R. E. Wrolstad, Anthocyanin pigment composition of blackberries, Journal of Food Science, 70 (2005) 198-202.

[10] F. C. Stintzing, A. S. Stintzing, R. Carle, R. E. Wrolstad, A novel zwitterionic anthocyanin from Evergreen blackberry (Rubus laciniatus Willd.), Journal of Agricultural and Food Chemistry, 50 (2002) 396-399.

[11] BEOU, P. K. Holmgren, N. H. Holmgren, L. C. Barnett, Index Herbariorum, Part 1, The Herbaria of the World, 1990, p 16476.

[12] G. Mazza, L. Fukumoto, P. Delaquis, B. Girard, B. Ewert, Anthocyanins, Phenolics, and color of cabernet Franc, Merlot, and Pinot Noir wines from British Columbia, Journal of Agricultural and Food Chemistry, 47 (1999) 4009-4017.

[13] B. C. Radovanovic, A. N. Radovanovic, J. M. Souquet, Phenolic profile and free radical-scavenging activity of Cabernet Sauvignon wines of different geographical origins from the Balkan region, Journal of the Science of Food and Agriculture 90 (2010) 2455-2461.

[14] C. W. Choi, S. C. Kim, S. S. Hwang, B. K. Choi, H. J. Ahn, M. Y. Lee, S. H. Park, K. Kim, Antioxidant activity and free radical scavenging capacity between Korean medicinal plants and flavonoids by assay-guided comparison, Plant Science, 163 (2002) 1161-1168.

[15] A. Munoz-Espada, K. Wood, B. Bordelon, B. Watkins, Anthocyanin Quantification and radical scavenging capacity of Concord, Norton and Marechal Foch grapes and wines. Journal of Agricultural and Food Chemistry, 52 (2004) 6779-6786.

[16] S. Häkkinen, M. Heinonen, S. Kärenlampi, H. Mykkänen, J. Ruuskanen, R. Törrönen, Screening of selected flavonoids and phenolic acids in 19 berries, Food Research International, 32 (1999) 345-353.

[17] X. Wu, L. Gu, R. L. Prior, S. McKay, Characterization of anthocyanins and proanthocyanins in some cultivars of Ribes, Aronia, and Sambucus and their antioxidant capacity, Journal of Agricultural and Food Chemistry, 52 (2004) 7846-7856. 


\section{Izvod \\ SADRŽAJ ANTOCIJANA I BIOAKTIVNOST EKSTRAKATA VOĆA SA VLASINE, DRENA (Cornus mas) I DIVLJE KUPINE (Rubus fruticosus)}

Ana Milenković Anđelković1 ${ }^{\star}$, Blaga Radovanović1, Marko Anđelković1, Aleksandra Radovanović ${ }^{1}$, Vesna Nikolić 2 , Vladimir Ranđelović ${ }^{3}$

1 Prirodno-matematički fakultet, Odsek za hemiju, Univerzitet u Nišu, Niš, Srbija

2 Tehnološki fakultet, Univerzitet u Nišu, Leskovac, Srbija

3 Prirodno-matematički fakultet, Odsek za biologiju, Univerzitet u Nišu, Niš, Srbija

Cilj ovog istraživanja bio je da se proceni antioksidativna i antimikrobna aktivnost ekstrakata bogatih antocijanima iz dve vrste divljih voćnih bobica iz jugoistočne Srbije i to dren (Cornus mas) i divlja kupina (Rubus fruticosus). Fenolni i antocijanidni sadržaj utvrđen je korišćenjem spektrofotometrijske i HPLC analize. Antioksidativna aktivnost je procenjena DPPH testom, dok su disk difuzioni i mikrodilucioni testovi upotrebljeni da se odredi njihovo antimikrobno dejstvo. Svi ekstrakti su pokazali visoku aktivnost hvatanja radikala i antimikrobnu aktivnost na svim testiranim bakterijskim sojevima. Ekstrakti divljeg bobičastog voća mogu biti pogodni za dobijanje različitih nutritvnih i farmaceutskih sastojaka.
(ORIGINALNI NAUČNI RAD)

UDK 547.973:582.788.1+582.712

Ključne reči: dren, divlja kupina, antocijani, antioksidativna aktivnost, antimikrobna aktivnost 